\title{
PREDICTORS OF NURSING WORKLOAD IN ELDERLY PATIENTS ADMITTED TO INTENSIVE CARE UNITS
}

\author{
Cleber Ricardo de Sousa ${ }^{1}$ \\ Leilane Andrade Gonçalves ${ }^{2}$ \\ Maria Cecília Toffoleto ${ }^{3}$ \\ Karine Leão ${ }^{3}$ \\ Kátia Grillo Padilha ${ }^{4}$
}

Sousa CR, Gonçalves LA, Toffoleto MC, Leão K, Padilha KG. Predictors of nursing workload in elderly patients admitted to intensive care units. Rev Latino-am Enfermagem 2008 março-abril; 16(2):218-23.

The age of patients is a controversial issue in admission to intensive care unit (ICU). The aim of this study was to compare severity and nursing workload of elderly patients with 60-69, 70-79, and e"80 years of age and to identify predictors of nursing workload in elderly patients. A cross sectional study was performed with a sample of 71 elderly patients admitted to three ICU in the city of Sao Paulo, Brazil from October to November 2004. Data were prospectively collected using Nursing Activities Score (NAS) and Simplified Acute Physiology Score II (SAPS II). There was no significant difference in nursing workload among the elderly patients age subgroups $(p=0.84)$. Multiple regression analysis indicated that the independent risk factors of high nursing workload were severity, age $e^{\prime \prime} 70$ years, and to be a surgical ICU patient. Age as an isolated factor should not be discriminative for elderly patients admission to ICU.

DESCRIPTORS: intensive care units; elderly; workload; nursing

\section{INDICADORES DE LA DEMANDA DE TRABAJO DE ENFERMERÍA PARA ATENDER ANCIANOS INTERNADOS EN UNA UNIDAD DE TERAPIA INTENSIVA}

La edad de los pacientes es un factor polémico en las internaciones en UTI(s). El objetivo del estudio fue comparar la gravedad y la demanda de trabajo que tiene enfermería para atender ancianos, agrupados en diferentes intervalos de edad, en la UTI, e identificar los indicadores de la alta carga de trabajo de enfermería en esa población. Se realizó un estudio transversal en tres UTI(s) de hospitales del municipio de San Pablo, con una muestra de 71 ancianos admitidos entre octubre y noviembre de 2004. Para la prospección y recolección de los datos se utilizó Nursing Activities Score (NAS) y el Simplified Acute Physiology Score II (SAPS II). No se encontraron diferencias en la demanda de trabajo de enfermería entre ancianos, agrupados en diferentes intervalos de edad; y, los factores asociados a la alta carga de trabajo fueron la gravedad, la edad y el tipo de internación. La edad como un factor aislado no debe constituirse en un factor discriminante para la admisión de ancianos en las UTIS.

DESCRIPTORES: unidades de terapia intensiva; ancianos; carga de trabajo; enfermería

\section{PREDITORES DA DEMANDA DE TRABALHO DE ENFERMAGEM PARA IDOSOS INTERNADOS EM UNIDADE DE TERAPIA INTENSIVA}

A idade dos pacientes é fator controverso na internação em UTIs. Foi objetivo deste estudo comparar a gravidade e a demanda de trabalho de enfermagem entre idosos, de diferentes faixas etárias, na UTI, e identificar os preditores da alta carga de trabalho de enfermagem para essa população. Realizou-se estudo transversal em três UTIs de hospitais do município de São Paulo, com amostra de 71 idosos, admitidos entre outubro e novembro de 2004. Os dados foram coletados prospectivamente utilizando-se o Nursing Activities Score (NAS) e o Simplified Acute Physiology Score II (SAPS II). Não houve diferença na demanda de trabalho de enfermagem para idosos de diferentes faixas etárias e os fatores associados à alta carga de trabalho foram a gravidade, a idade e o tipo de internação. A idade, como fator isolado, não deve ser discriminante para a admissão de idosos em UTI.

DESCRITORES: unidades de terapia intensiva; idoso; carga de trabalho; enfermagem

${ }^{1}$ RN, Hospital Nove de Julho, First Aid Post, Brazil, e-mail: cleber73@gmail.com; ${ }^{2}$ MS in Nursing, RN, Hospital Sírio Libanês, Brazil, e-mail: leilaneag@yahoo.com.br

${ }^{3}$ RN, Doctoral Student, e-mail: mariacel@usp.br, karileao@usp.br; ${ }^{4}$ RN, Associated Professor, e-mail:kgpadilh@usp.br. University of Sao Paulo, School of Nursing Brazil 


\section{INTRODUCTION}

Ageing of the world population is occurring in a large scale in the last decades. This phenomenon occurs not only in developed countries but also in developing, and its results in society are sizeable, especially regarding health ${ }^{(1)}$. Because of this process, the number of chronic diseases characterized by organic instable disorders has increased among older people, which results in increase demand for beds in Intensive Care Units (ICU) to meet the needs of these patients ${ }^{(2)}$.

ICUs are costly, requiring the use of high technology, appropriate room and highly trained team. Studies show that the single largest contributor to an ICU cost is nursing services. Therefore, one strategy to lower cost of care is scheduling nurse staff adequately. Staff schedules should be driven by patient needs of care in order to ensure a rational use of the ICU resources ${ }^{(3)}$. To that end, it is important to be aware of the participation of the elderly patients in this context and to see to what extent patients from this age group consume more nursing workload for their care.

Regarding the cost of ICUs, in the United States, of $\$ 989$ billion dollars spent in health services, $\$ 70$ billion dollars, that is, $14 \%$, are spent with intensive care. A great part of this amount is spent in care of elderly patients before their death. Patients over 65 years old account for $28 \%$ of the total costs of ICU, $77 \%$ of these costs occur in the last year of life, and $40 \%$ in the last month of life ${ }^{(4)}$.

Within this context, admission of elderly patients in ICUs is a controversial issue, and age is considered as a refusal criterion for these patients in some centers ${ }^{(5-6)}$. In the literature, there is no consensus on the issue of investing resources in elderly patients admitted to a hospital, especially when they demand ICU hospitalization. Mortality of these patients is high, especially when associated with the use of invasive mechanical ventilation, reaching up to $92 \%$ among elderly people over 75 years old ${ }^{(7)}$.

Thus, it is essential to assess the demand of nursing work of this population, aiming at identifying the factors related to it so that age does not become a discriminating factor in ICU care. Therefore, the present study aimed to describe the nursing workload among elderly patients, to compare nursing work demand, severity, and mortality risk among elderly patients in ascending age groups, and to identify predictors of high nursing work demand in these groups of patients.

\section{PATIENTS AND METHODS}

Data were collected in October and November 2004. The inclusion criteria were older than 60 years of age, minimal ICU stay of 24 hours and maximum
30 days. Elderly patients were divided into three subgroups, according to their age: A (60-69), B (7079) and group $C(\geq 80)$.

For data collection, the study instruments included an instruments for identification of demographic and clinical characteristics, the Nursing Activities Score (NAS) to assess nursing work demand, and the Simplified Acute Physiology Score (SAPS II) to assess patient severity and mortality risk.

NAS is an instrument that scores needs for care required by patients in 24 hours, as of the quantification of interventions performed in this period of time. It consists of 23 items divided into seven intervention categories. Each item receives a score whose final grade shows the percentage of time spent by nurses in direct care of patients; it may range from 0 to $100 \%$ or over. NAS supplies data for staff quantification and also helps calculating budget for nursing service of hospitals ${ }^{(8)}$.

SAPS II is an instrument to measure severity obtained from the assessment of clinical and laboratory features and of the existence of chronic comorbidities. The final score, applied to a math formula, enables to calculate the mortality risk at $\mathrm{ICU}^{(9)}$.

After the Project was approved by the Ethical Committee of the hospital fields of study, prospective follow-up of patients were performed, considering a minimum period of admission to ICU of $24 \mathrm{~h}$ and a maximum of 30 days, when data collection was stopped.

For data collection of NAS, in the first admission day, the interventions performed from admission at ICU until 8 o'clock the next day were computed, regardless of completing 24 hours. Regarding patients leaving the unit, interventions computed were those from 8 o'clock and the time of discharge or death. NAS was applied by nursing aids of the respective ICUs, using information from the patient medical records and daily patient worksheet.

SAPS II was collected only on the first day of stay, also with data from medical records, from the time of ICU admission until 8 o'clock in the morning of the following day, regardless of completing 24 hours.

Data were stored and assessed using SPSS program version 12.0 and the regression analysis were performed at MULT-L-R. Adherence to normal distribution was assessed using Kolmogorov-Smirnov test. Inference analysis included the following tests: Chi-square, Student's t-test, ANOVA, with post-hoc analysis with Bonferroni test, and univariate and multiple logistic regressions.

In the logistic regression models, nursing workload assessed by Nursing Activities Score (NAS), was considered as a dependent variable, and it was changed into a binary variable: high (1) and low load (0). Transformation considered the median from the 
total NAS score in the sample. Elderly patients with score higher than or equal to $71.1 \%$ were considered as high nursing workload and scored lower than $71.1 \%$ were considered as low workload.

Univariate analysis were performed among the independent variables: age $(60-69=0,70-79=1$ and $\geq 80=2$ ), gender (female and male), severity (high risk=1 and low risk=0), defined according to values above and below the median of SAPS II. Multiple logistic regression was performed including in the model all variables with $p$-value lower than 0.20 .

In all analyses, a p-value less than 0.05 indicates significance.

\section{RESULTS}

Sociodemographic and clinical characteristics

Elderly patients were equally distributed according to gender, with a $75.8(\mathrm{SD}=9.9)$ mean age.
They were mostly coming from the Emergency room $(40.8 \%)$, admitted due to clinical changes $(74.0 \%)$, especially cardiologic (26.8\%), gastrointestinal $(26.8 \%)$ and respiratory $(22.5 \%)$, and they stayed at ICU for 13.9 days on average $(S D=14.2)$. Distribution of elderly patients according to sociodemographic characteristics did not differ significantly among the age groups, although among 60-69 year olds, most of them were females (57.1\%) (Table 1 ).

Regarding clinical characteristics, the oldest $(\geq 80)$ stayed in hospital for a significantly longer time than those with 60-69 years of age $(p=0.006)$, and also presented a greater mortality risk $(p=0.026)$. Although elderly patients with ages from 70-79 presented greater risk than those from 60-69, this difference was not statistically significant (Table 1 ).

When elderly patients from the different age groups were compared, no statistically significant difference was seen regarding severity (SAPS II), although there were significant differences in death risk (Table 1).

Table 1 - Distribution of patients according to demographic and clinical characteristcs. São Paulo, 2004

\begin{tabular}{|c|c|c|c|c|c|c|c|c|c|}
\hline \multirow{2}{*}{ Variables } & \multicolumn{2}{|c|}{ General $(n=71)$} & \multicolumn{2}{|c|}{60 to 69} & \multicolumn{2}{|c|}{70 to 79} & \multicolumn{2}{|c|}{$\geq 80$} & \multirow{2}{*}{$\begin{array}{l}\text { p-value, Bonferroni's } \\
\text { adjustment }\end{array}$} \\
\hline & $\mathbf{n}^{\circ}$ & $\%$ & $\mathrm{n}^{\circ}$ & $\%$ & no & $\%$ & $\mathrm{n}^{\circ}$ & $\%$ & \\
\hline Gender & & & & & & & & & $0.885^{\mathrm{a}}$ \\
\hline Female & 33 & 46.5 & 9 & 42.9 & 13 & 50 & 11 & 45.8 & \\
\hline Male & 38 & 53.5 & 12 & 57.1 & 13 & 50 & 13 & 54.2 & \\
\hline Age & & & & & & & & & - \\
\hline Mean (SD) median, min-max & \multicolumn{2}{|c|}{75.8 (9.9) 74, 60-97 } & \multicolumn{2}{|c|}{65.2 (3) 66, 60-69 } & \multicolumn{2}{|c|}{73.1 (2.6) 73, 70-78 } & \multicolumn{2}{|c|}{87.9 (4.9) 88.5, 80-97 } & \\
\hline Coming from & & & & & & & & & $0.254^{\mathrm{a}}$ \\
\hline Admission ward & 6 & 8.5 & 0 & 0 & 2 & 7.6 & 4 & 16.7 & \\
\hline Surgeny & 16 & 22.5 & 4 & 19 & 8 & 30.8 & 4 & 16.7 & \\
\hline Emergency & 29 & 40.8 & 13 & 61.9 & 8 & 30.8 & 8 & 33.3 & \\
\hline Another hospital & 2 & 2.8 & 1 & 4.8 & 0 & 0 & 1 & 4.1 & \\
\hline Semi Intensive & 11 & 15.5 & 3 & 14.3 & 4 & 15.4 & 4 & 16.7 & \\
\hline Heart disease Unit & 7 & 9.9 & 0 & 0 & 4 & 15.4 & 3 & 12.5 & \\
\hline Type of Admission & & & & & & & & & $0.742^{\mathrm{a}}$ \\
\hline Surgical & 13 & 26 & 3 & 20 & 6 & 31.6 & 4 & 25 & \\
\hline Clinical & 37 & 74 & 12 & 80 & 13 & 68.4 & 12 & 75 & \\
\hline Reason for Admission & & & & & & & & & - \\
\hline Cardiologic & 19 & 26.8 & 7 & 33.3 & 7 & 26.9 & 5 & 20.8 & \\
\hline Gastrointestinal & 19 & 26.8 & 6 & 28.6 & 8 & 30.8 & 5 & 20.8 & \\
\hline Respiratory & 16 & 22.5 & 4 & 19 & 4 & 15.4 & 8 & 33.3 & \\
\hline Neurological & 7 & 9.8 & 3 & 14.3 & 0 & 0 & 4 & 16.8 & \\
\hline Other* & 10 & 14.1 & 1 & 4.8 & 7 & 26.9 & 2 & 8.3 & \\
\hline Mortality risk & \multirow{2}{*}{\multicolumn{2}{|c|}{$25.44(24.4) 17,1-88$}} & \multirow{2}{*}{\multicolumn{2}{|c|}{$15.82(20.24) 8,2-86$}} & \multirow{2}{*}{\multicolumn{2}{|c|}{24.77 (22.8) 19.5, 1-88 }} & & & $0.034^{b, c}, ; \geq 80>60-69=0.026$ \\
\hline $\begin{array}{l}\text { Mean (SD) median, min-max } \\
\text { Severity (SAPSII) }\end{array}$ & & & & & & & \multicolumn{2}{|c|}{34.60 (26.82) 32, 1-80 } & \\
\hline Low risk & 39 & 54.9 & 18 & 85.7 & 13 & 50 & 8 & 33.3 & \\
\hline High risk & 32 & 45.1 & 3 & 14.3 & 13 & 50 & 16 & 66.7 & \\
\hline $\begin{array}{l}\text { Mean (SD) median, min-max } \\
\text { Length of stay }\end{array}$ & \multicolumn{2}{|c|}{36.4 (15.8) 38, 9-74 } & \multicolumn{2}{|c|}{30.8 (13) 27, 16-72 } & \multicolumn{2}{|c|}{36.3 (15.3) 37, 9-74 } & \multicolumn{2}{|c|}{41.5 (16.8) 43.5, 9-67 } & $\begin{array}{l}0.070^{\mathrm{b}, \mathrm{d}} \\
\mathbf{0 . 1 4 4 ^ { \mathrm { a } }}\end{array}$ \\
\hline $1 \vdash 6$ days & 31 & 48.4 & 12 & 57.1 & 13 & 56.6 & 6 & 30 & \\
\hline $6 \vdash 10$ days & 10 & 15.6 & 1 & 4.8 & 5 & 21,7 & 4 & 20 & \\
\hline$\geq 10$ days & 23 & 35.9 & 8 & 38.1 & 5 & 21.7 & 10 & 50 & \\
\hline $\begin{array}{l}\text { Mean (SD) median, min-max } \\
\text { Type of discharge }\end{array}$ & \multicolumn{2}{|c|}{13.9 (14.2) 9, 1-53 } & \multicolumn{2}{|c|}{7.5 (6.9) $6,1-24$} & \multicolumn{2}{|c|}{$13.4(15.2) 8,1-53$} & \multicolumn{2}{|c|}{21 (15.7) 21.5, 1-50 } & $\begin{array}{c}0.009 ; \geq 80>60-69=0.006 . \\
0.164^{\mathrm{a}}\end{array}$ \\
\hline Admission Unit & 44 & 68.8 & 16 & 76.2 & 14 & 60.9 & 14 & 70 & \\
\hline Death & 11 & 17.2 & 1 & 4.8 & 6 & 26.1 & 4 & 20 & \\
\hline Semi-intensive & 2 & 3.1 & 0 & 0 & 2 & 8.7 & 0 & 0 & \\
\hline Heart Unit & 7 & 10.9 & 4 & 19 & 1 & 4.3 & 2 & 10 & \\
\hline Workload (NAS) & & & & & & & & & $0.360^{\mathrm{a}}$ \\
\hline Low load & 40 & 56.3 & 14 & 66.7 & 12 & 46.2 & 14 & 58.3 & \\
\hline High load & 31 & 43.7 & 7 & 33.3 & 14 & 53.8 & 10 & 41.7 & \\
\hline Mean (SD) median, min-max & $72.93(14$ & $71.1,54-110$ & $72.43(17$. & $67.2,54-110$ & $74.25(13,87) 7$ & $75.1,54-97$ & $71.93(13$ & $70.65,54-93$ & $0.842^{\mathrm{b}, \mathrm{d}}$ \\
\hline
\end{tabular}


Charateristics of the nursing work demand

Mean nursing work demand obtained with NAS application was $72.9 \%(S D=14.5)$. When nursing workload was classified as high or low, 40 patients (56.3\%) demanded low load and 31 (43.7\%) highy workload (Table 1).

When the three groups of elderly patients were compared, we saw that there was no statistically significant differences in the total score of the nursing work demand among elderly in different age groups $(p=0.84)$ and also when compared with the distribution of elderly in high and low demand $(p=0.36)$. Notwithstanding, among elderly patients from 60-69, more than a third $(66.7 \%)$ demanded low load and among those from 70-79, the majority (53.8\%) demanded high nursing workload (Table 1).

Factors associated with high nursing work demand

To identify predictors of high nursing workload, all sociodemographic and clinical variables were assessed using univariate logistic regression. Only severity, age and type of admission presented an independent effect in determining high nursing work demand. Patients with ages ranging from 70-79 presented greater chance of high nursing workload than those from 60-69, especially when they were patients admitted for surgical reasons and that were high severe. OR (Odds Ratio) of the age was adjusted according to severity and type of admission (Table 2).

Table 2 - Logistic regression analysis for high nursing workload. São Paulo, 2004

\begin{tabular}{lccc}
\hline \multicolumn{1}{c}{ Variables } & $\begin{array}{c}\text { Adjusted Odds } \\
\text { Ratio (OR) }\end{array}$ & Cl (95\%) & p-value \\
\hline Age & 1 & & \\
60 - 69 & 4.56 & $1.05-19.87$ & 0.0433 \\
$70+79$ & 3.65 & $0.79-16.93$ & 0.0983 \\
$\geq 80$ & & & \\
Severity & 1 & & \\
High risk & 0.18 & $0.49-0.67$ & 0.0107 \\
Low risk & & & \\
Type of Admission & 1 & & 0.04 \\
Clinical & 5.07 & $1.08-23.92$ & \\
Surgical & & & \\
\hline
\end{tabular}

\section{DISCUSSION}

Results referring to demographic and clinical characteristics of the total of patients in this study are similar to most research performed at ICU regarding male predominance $(53.5 \%)^{(8)}$, high age average ${ }^{(10)}$, coming from Emergency Room $(E R)^{(10)}$, with cardiac, respiratory and gastrointestinal changes ${ }^{(11)}$, admitted to ICU for clinical treatment ${ }^{(10)}$. These data confirm that with the ageing of the population, health problems increase with the need for interventions demanding ICU stay. Also, admission in ER allows us to infer that old patients, with chronic diseases, were referred to ER with severe instability requiring intensive care.

The high SAPS II found in the sample (38.4) confirms the information presented above, and they are compatible with some national studies ${ }^{(9)}$, however, they are higher when compared with other national and international investigations ${ }^{(12)}$. Additionally, it was observed a long average of stay (13.9 \pm 14.2 days), different from findings of studies with average between 3 and 6 days $^{(11)}$, demonstrating the need for intensive care for a longer period of time for this specific population.

Regarding characterization of the nursing work demand required by the elderly patients, a high average of the total score of NAS was observed $(72.9 \%)$, with a minimum of $54 \%$ and maximum of $110 \%$, superior to several national studies ${ }^{(8)}$, including a study that compared workload among elderly and non-elderly ${ }^{(10)}$, whose average of NAS varied from $65.5 \%$ to $69.9 \%$.

Although patients from the present study were in an advanced age, severe and demanding a high workload, mortality rate was low (17.2\%), in agreement with foreign studies ${ }^{(10,13)}$, with the majority of patients $(68.8 \%)$ being transferred to admission unit after ICU discharge. With these findings we may assume that patients received quality medical and nursing care, thus justifying the low mortality rate found.

From a quantitative standpoint of nursing personnel, considering the high work demand of elderly (about $73 \%$ ), the 1:2 professional relationship nurse/patients recommended by the Regulation of the Ministry of Health ${ }^{(14)}$, would be enough for the care of patients in this population, according to work shift, which would demand one professional per shift for their care.

Assessing the variables in the different age groups in this survey, we verified that in groups $A, B$ and $C$ most or great part of the patients came from the emergency room, with clinical disturbances and was discharged to the admission unit. 
Although the variables gender, severity, type of discharge and reason for admission were different among patients of the three age groups, there was no statistically significant difference among the groups. However, groups differed regarding mortality risk and length of ICU stay.

Among patients from group A (60 to 69), most of them were women (57.1\%), remaining at ICU 1 to 5 days $(57.1 \%)$, cardiac problems were responsible for ICU stay in $33.3 \%$ of cases, low risk picture occurred in $85.7 \%$, and mortality was low (4,8\%).

Regarding group B (70 to 79), most patients $(56.6 \%)$ remained 6 to 10 days, with no difference in the proportion among genders (female/male) and the severity (high risk/low risk), however, a great part $(30.8 \%)$ was referred to ICU due to gastrointestinal complications and presented higher mortality rate (26.1\%).

As for group C $(\geq 80)$, it was observed that $50 \%$ remained at ICU for 10 days or over, most of them (54.2\%) were male presenting high risk $(66.7 \%)$. Mortality rate was also considered high $(20 \%)$, higher than that seen in group $A$ and lower than that found in group $B$, many patients $(33.8 \%)$ were referred to ICU due to respiratory problems.

From this, we may assume that, in the present study, as age advanced, as increased the length of stay in ICU. Regarding the severity, there was difference only among younger elderly patients and those $\geq 80$, the same thing occurred regarding mortality, demonstrating that the more advanced the age, the greater the need for intensive care, due to the high mortality risk that was statistically significant among the groups.

Assessing the nursing workload among the three age groups studied, a close NAS average was observed among them, with values $72.4 \%, 74.3 \%$, and $71.9 \%$, respectively, in groups $A, B$, and $C$.

When NAS variables were compared with the variables gender, length of stay, type of admission and age group, it was seen using univariate analysis that the only variable related with the demand of nursing work with significant value was type of admission, showing that surgical patients required greater nursing care when compared to those admitted due to clinical disturbances, presenting respectively $83.5 \%$ and $72.1 \%$ NAS $(p=0.036)$. However, in the logistic regression model, only severity, age and type of admission had an independent effect in determining high nursing work demand, showing that patients from 70-79 years old presented greater chance of high workload than those aged 60-69 years old, especially when these were extremely severe patients admitted for clinical reasons.

From these findings, one may assume that the nursing workload was not significantly different among elderly patients from ascending age groups, indicating, in this sample, that the assumption that the older the patient the greater the nursing workload is not real.

Concerning predictors of high nursing work demand among elderly patients, the logistic regression model showed that more severe patients, when compared to less severe, were those that demanded greater nursing workload. It was also seen, that patients with ages ranging from 70 to 79 required greater nursing efforts than those considered as younger. Therefore, factors associated with high nursing work of elderly patients admitted to ICUs studied were severity, type of admission, and age.

Stays of elderly patients at ICUs are undergoing strict criteria in American and European ICUs, such as in France, where studies show that one of the criteria associated with refusal for a bed at ICU is the age of patients, especially if associated with a chronic disease ${ }^{(5)}$. A study conducted in 5 English hospitals reinforces age as criteria for ICU admission, verifying that after assessment of an intensive care physician, about 50\% of the elderly patients that were being taken care of by general nurses would be more suitably cared for if seen at ICUs ${ }^{(6)}$. These results confirm that the access to these units by the elderly population is already being restricted which may hinder the care of elderly who might benefit from intensive care.

There is no consensus in the literature on the issue of investing resources in elderly patients staying in a hospital, especially when they require ICUs stays. However, regarding cardiac resuscitation, a study performed in the USA demonstrates that written orders for non-resuscitation increase sizably with age going from $8 \%$ in patients below 65 to $32.6 \%$ in patients 85 or over ${ }^{(15)}$

Analysis of the results obtained showed that nursing work demand of elderly patients, as well as the severity and the risk of mortality were increased in this population, with high mortality in patients aged 80 or over. Thus, the expressive need for nursing care taking up more than $70 \%$ of the working time of a nursing professional seems justified. It was also 
interesting to see by the use of NAS that there was no difference in the application of therapy resources between elderly and non-elderly patients, demonstrating that, once admitted to ICU, regardless of the age, patients received all kinds of investment available for their treatment.

Results of this investigation point out for the need to increase the discussion on the referral of elderly to ICU because of the high financial, physical and emotional cost of care in this Unit. Obviously, it is not about discouraging referral of elderly to ICU, but deepening the discussion on the issue aiming at balanced and sensible decisions on how much investment should be given to treatment, without lowering human beings. However, other studies must be performed to explore the issue, because of the small number of research assessing the nursing workload of elderly staying at ICU (s).

\section{REFERENCES}

1. Kalache A, Veras RP, Ramos LR. O envelhecimento da população mundial: um desafio novo. Rev Saúde Pública 1987; 21(3):200-10.

2. Pedreira LC, Lopes RM, Oliveira C. Importância da capacitação de recursos humanos para o cuidado ao idoso na UTI. Rev Nursing 2003; 70(7):21-4.

3. Telles SCR. Custos de pessoal na assistência direta de enfermagem em unidade de terapia intensiva. [tese] São Paulo (SP): Escola de Enfermagem da Universidade de São Paulo; 2003.

4. Hamel MB, Teno JM, Goldman L, Lynn J, Davis RB, Galanos AN et al. Patient age and decisions to withhold life-sustaining treatments from seriously ill, hospitalized adults. Ann Intern Med 1999; 130(2):116-25.

5. Azoulay E, Pochard F, Chevret S, Vinsonneau C, Garroueste $M$, Cohen $Y$ et al. Compliance with triage to intensive care recommendations. Crit Care Med 2001; 29(11):2132-6.

6. Hubbard RE, Lyons RA, Woodhouse KW, Hillier SL, Wareham K, Ferguson $B$ et al. Absence of ageism in access to critical care: a cross-sectional study. Age Ageing 2003; 32(4):382-7.

7. Carson SS, Bach PB, Brzozowski L, Leff A. Outcomes after long-term acute care. An analisys of 133 mechanically ventilated patients. Am J Resp and Crit Care Med 1999; 159(5Pt 1):1568-73.

8. Queijo AMG, Padilha KG. Instrumento de medida da carga de trabalho de enfermagem em Unidades de Terapia Intensiva: Nursing Activities Score (N.A.S.). Rev Paul Enferm 2004; 23(2):114-22.

9. Le Gall JR, Lemeshow S, Saulnier F. A new simplified acute physiology score (SAPS II) based on a European/North American multicenter study. JAMA 1993; 270:2957-63.

\section{CONCLUSIONS}

The results of the study in this sample of patients allowed us to conclude that nursing work demand of elderly patients of age groups 60-69, 7079 and $\geq 80$, at ICU, was high, respectively, $72.43 \%$, $74.25 \%$, and $71.93 \%$. Patients undergoing surgical treatment demanded greater nursing workload $(p=0.036)$, and elderly patients aged 80 or over presented higher mortality risk $(p=0.034)$. There was no difference between the groups regarding severity $(p=0.070)$ and nursing workload $(p=0.842)$. Factors associated with high nursing work demand at ICU were age, severity, and type of admission in the Unit. Results indicate the need for a greater number of studies on the issue, so that the age does not become a discriminative factor for care of elderly patients at ICU.
10. Ciampone JT, Gonçalves LA, Maia FOM, Padilha KG. Necessidades de cuidados de enfermagem e intervenções terapêuticas em Unidade de Terapia Intensiva: estudo comparativo entre pacientes idosos e não idosos. Acta Paul Enferm 2006; 19(1):28-35.

11. Associação de Medicina Intensiva Brasileira (AMIB). $2^{\circ}$ Anuário Brasileiro de Unidades de Terapia Intensiva; $2002 / 2003$.

12. Rothen HU, Kung V, Ryser DH, Zurcher R, Regli B. Validation of "Nine equivalents of nursing manpower use score "on an independent data sample. Intensive Care Med 1999; 25(6):606-11.

13. Miranda DR, Raoul N, Rijk A. Schaufeli W, Iapichino G. Nursing activities score. Crit Care Med 2003; 31(2):37482.

14. Brasil. Ministério da Saúde. Portaria n. 3432, de 12 de agosto de 1998. Estabelece critérios de classificação para as unidades de tratamento intensivo-UTI. Diário Oficial da União, Brasília, 13 ago. 1998. Seção 1, p.108-10.

15. Boyd K, Teres D, Rapoport J, Lemeshow S. The relationship between age and the use of DNR orders in critical care patients. Evidence for age discrimination. Arch Internal Med 1996; 156(16):1821-6. 